\title{
PENDAMPINGAN PEMBUATAN FOTO UNTUK GURU SD KECAMATAN SUKAMAKMUR KABUPATEN BOGOR
}

\author{
Zuhdy HS, Nurdin Ibrahim, Cecep Kustandi \\ Universitas Negeri Jakarta \\ Email: cecep_kustandi@unj.ac.id
}

\begin{abstract}
The low student learning outcomes of SDN Sukamakmur Bogor District based on the analysis conducted because teachers still use the traditional approach, marked by still dominant activity while students are only as listeners and recipients of information. students only listen to the teacher's explanation and take notes or summarize the important things from the material presented. Therefore it is necessary to strive for the use of media and appropriate in the learning process, an interesting atmosphere so that students are more active in learning so that students' learning activities and outcomes increase. The approach applied to the Community Service Program is a model of empowerment through mentoring with the following steps: 1) Preparation Phase; 2) Assessment Phase; 3) Alternative Planning Phase of Programs or Activities; 4) Formulation Phase of the Action Plan; 5) Stage of Implementation (Implementation) of the Program or Activity; 6) Evaluation Phase; and 7) Termination Phase. This Community Service is carried out as an empowerment of elementary school teachers in the District of Sukamakmur, Bogor Regency, producing Photo Media that meets theoretically feasible criteria; meet the proper criteria in terms of format, content and appearance; have high applicability or are worthy of learning.
\end{abstract}

Keywords: media foto, guru SD, Kecamatan Sukamakmur Bogor, media pembelajaran, pendampingan

\section{ANALISIS SITUASI}

Guru merupakan faktor kunci dalam peningkatan mutu pendidikan. Dalam memikul perannya sebagai agen pembaharuan, maka guru terus dituntut untuk mengembangkan kemampuannya baik kemampuan akademik, maupun kemampuan profesionalnya. Dalam kemampuan akademik guru harus senantiasa mengikuti perkembangan ilmu dan teknologi serta perkembangan terbaru dari bidang studi yang ditekuninya. Sementara itu dalam bidang pengembangan profesinya, guru dituntut terus menerus melakukan inovasi pembelajaran sehingga memiliki keterampilan dalam pemilihan media dan pengetahuan akan model-model pembelajaran ataupun strategi pembelajaran yang diterapkannya kepada siswa berlangsung dalam kondisi pembelajaran aktif, kreatif, efektif dan menyenangkan. Dengan meningkatnya kemampuan guru pada dua bidang ini, maka diharapkan akan meningkatkan kualitas lulusan yang dihasilkannya.

Problematika yang dihadapi guruguru di SD Sukamakmur Kecamatan Sukamakmur Kabupaten Bogor untuk dapat menerapkan pembelajaran adalah terbatasnya keterampilan guru dalam mengembangkan dan memanfaatkan media pembelajaran.

Media pembelajaran merupakan perantara atau pengantar pesan dari pengirim kepada penerima yaitu guru kepada siswa agar penerima atau siswa tersebut mempunyai motivasi untuk belajar dengan harapan dapat memperoleh hasil belajar yang lebih memuaskan, sedangkan untuk bentuk dari media pembelajaran tersebut dapat berbentuk cetak maupun non cetak (Mudhofir dan Evi, 2016). Media dapat dikatakan sebagai segala bentuk dan saluran yang digunakan orang untuk menyampaikan pesan atau informasi yang tidak terbatas pada jenis media yang dirancang secara khusus untuk tujuan tertentu tetapi juga 
keberadaannya yang dapat digunakan untuk menyalurkan pesan (Prasetya, 2014: 2).

Penggunaan media visual dapat membantu peserta didik untuk menghubungkan materi pelajaran dengan lingkungan sekitar sehingga konsep dan materi yang sulit dipahami dapat dipelajari dengan mudah. Media visual dapat berbentuk grafik, bagan, gambar diagram maupun maupun foto yang disajikan guru dalam proses pembelajaran. Foto dapat digunakan sebagai media penyampaian pesan pembelajaran. Dalam penggunaannya dapat dibalik jika pesan dalam lembaran depan sudah ditampilkan dan diganti dengan lembaran berikutnya yang sudah disediakan. Sedangkan menurut Indriana (2011:66). Berdasarkan uraian di atas perlu dilakukan upaya memberikan keterampilan dalam pemilihan, produksi, pemanfaatan dan evaluasi media Foto kepada guru-guru di Kecamatan Sukamakmur Kabupaten Bogor khususnya SD Sukamakmur 1, 2 dan 3 dalam bentuk pendampingan.

Salah satu cara yang dilaksanakan untuk mengembangkan kualitas kemampuan akademik dan kemampuan profesional keguruan adalah mengadakan pelatihan terbimbing yaitu suatu kegiatan yang dilakukan dengan melatih guru-guru dalam mengembangkan media pembelajaran melalui pendampingan dari instruktur atau fasilitator. Hal ini dilakukan dengan tujuan untuk menghasilkan Foto yang memenuhi kriteria layak secara teoritik dari ahli materi; memenuhi kriteria layak dari segi format, isi dan tampilan dari ahli media; memiliki keterterapan tinggi atau layak dalam pembelajaran menurut pengguna (guru dan siswa). Tujuan dari pengabdian kepada masyarakat ini adalah pendampingan merencanakan, mengembangkan, memanfaatkan dan menilai media foto yang dikembangkan dalam proses pembelajaran.

Kehadiran Program Studi Teknologi

Pendidikan Fakultas Ilmu Pendidikan Universitas Negeri Jakarta dalam pengembangan keilmuan melalui penelitian- penelitian yang dilakukan diantaranya melaksanakan penelitian yang bermanfaat untuk memecahkan masalah belajar dan pembelajaran, serta memberikan layanan jasa dalam memecahkan masalah belajar dan pembelajaran dengan menerapkan pendekatan sistem, sehingga berdasarkan uraian di atas dapat disimpulkan bahwa diperlukan sebuah upaya kegiatan pendampingan merancang, mengembangkan, memanfaatkan, dan mengevaluasi media foto untuk guru SD Kecamatan Sukamakmur Kabupaten Bogor Jawa Barat dalam sebuah program pengabdian masyarakat.

\section{METODE PELAKSANAAN}

Langkah-langkah yang dilakukan dalam upaya meningkatkan kompetensi guru sebagai sebuah upaya kegiatan pendampingan merancang, mengembangkan, memanfaatkan, dan mengevaluasi media foto untuk guru SD Kecamatan Sukamakmur Kabupaten Bogor Jawa Barat dilakukan melalui langkahlangkah sebagai berikut:

1) Melakukan analisis kondisi sekolah, guru dan lingkungan yang ada di desa Sukamakmur.

2) Mempersiapkan bahan pelatihan berupa bahan presentasi dan format dokumen yang dapat memudahkan peserta (guru) dalam memanfaatkan lingkungan sebagai sumber belajar.

3) Melaksanakan PKM dengan melakukan presentasi dan pendampingan agara peserta memahami bagaimana pengembangan media foto untuk guru SD.

4) Peserta diminta untuk membuat media dengan alat-alat yang sudah disediakan.

5) Beberapa peserta diminta untuk maju dan mempresentasikan hasil karyanya sebagai media foto.

6) Melakukan pembahasan terhadap pengembangan media foto untuk Guru SD 
7) Tindak lanjut: Melakukan evaluasi terhadap media foto yang sudah dibuat oleh peserta.

Kegiatan pendampingan merancang, mengembangkan, memanfaatkan, dan mengevaluasi media foto untuk guru SD Kecamatan Sukamakmur Kabupaten Bogor Jawa Barat dilakukan dalam rangkaian kegiatan seperti pada tabel 1 berikut:

Tabel 1. Pelaksanaan Kegiatan

\begin{tabular}{ll}
\hline Kegiatan & Pelaksanaan \\
\hline Pra Kegiatan & Rabu, 21 Agustus 2019 di \\
1 & Kantor Kecamatan \\
Pra Kegiatan & Sukamakmur, Bogor \\
2 & Rabu, 28 Agustus 2019 \\
& Kantor Kecamatan \\
& Sukamakmur, Bogor \\
Pembukaan & Sabtu, 7 September 2019 \\
& di Gedung PGRI \\
& Sukamakmur \\
Pelaksanaan & 9-14 September 2019 di \\
Penerapan di & Sekolah-sekolah \\
Sekolah- & Kecamatan Sukamakmur, \\
sekolah & Bogor \\
Monitoring & Sabtu, 21 September \\
dan evaluasi & 2019 di Gedung SD \\
& Sukamakmur \\
& Kecamatan Sukamakmur \\
& Bogor Jawa Barat.
\end{tabular}

Berdasarkan evaluasi reaksi kegiatan pendampingan ini didapatkan hasil yang ditunjukkan pada tabel 2 sebagai berikut:

Tabel 2. Hasil Evaluasi Reaksi

\begin{tabular}{cc}
\hline Aspek & Nilai \\
\hline Trainer & 4.23 \\
Materi & 4.46 \\
Pelatihan & \\
Media & 4.48 \\
Pelatihan & 4.38 \\
Pelatihan & 4.42 \\
Latihan/Tugas & 4.38 \\
Fasilitas & 4.39 \\
Rerata &
\end{tabular}

Selanjutnya berdasarkan kegiatan monitoring yang diwujudkan dengan pengerjaan tugas-tugas yang diberikan yaitu pengembangan media sederhana foto, kemudian peserta mengirimkan rekaman atau dokumentasi ketika mereka sedang memanfaatkan foto tersebut di dalam kelas. Selanjutnya didapatkan komentar yang ditunjukkan pada tabel 3 .

Tabel 3. Komentar Peserta Terhadap Pelaksanaan Pendampingan

\section{Komentar}

1. Pelatihan pengembangan media foto ini sangat membantu sekali bagi guru SD dalam mengembangkan pembelajaran yang menarik.

2. Kegiatan ini sangat bermanfaat bagi guru hanya terlalu cepat dalam menyampaikan materi.

3. Saya ucapkan terima kasih kepada tim dosen UNJ karena telah memberikan ilmu kepada kami khususnya saya pribadi karena dengan diadakannya pelatihan ini bertambah ilmu saya dalam pembuatan media foto, saran mudah mudahan acara seperti ini tidak hanya 1 kali saja tapi ada tindak lanjut lagi.

4. Kegiatan ini sangat bagus karena menjadikan guru lebih kreatif dan dapat menarik minat anak untuk belajar, dengan baik dan lebih paham akan materi yang disampaikan.

5. Dengan adanya pengembangan media foto ini mudah-mudahan lebih baik lagi dan bisa menggunakan fotonya yang ada di lingkungan sekitar.

6. Pelatihan pendampingan ini sangat bermanfaat untuk guru-guru dan bisa dikembangkan kepada peserta didik di sekolah masing-masing.

7. Dalam kegiatan pendampingan pengembangan foto untuk guru SD ini kami dapat menambah ilmu dan semoga kegiatan ini berkelanjutan.

8. Sangat menarik menambah ilmu kembali untuk kami para guru sekolah dasar. 
9. Semoga kegiatan ini terus berkelanjutan dengan materi - materi yang lain yang dapat menambah wawasan kami guru sekolah dasar.

10. Menurut saya kegiatan ini memberikan ilmu yang bermanfaat dan relevan dengan kebutuhan kami sebagai guru dimana media pembelajaran adalah salah satu komponen yang sangat penting dalam pembelajaran. Dengan adanya kegiatan ini kami menjadi tahu bahwa media pembelajaran ternyata mudah dibuat dan alat serta bahan pun banyak tersedia disekitar kita.

Setelah melalui $\begin{array}{r}\text { kegiatan } \\ \text { merancang, }\end{array}$
pendampingan
mengembangkan, memanfaatkan, dan
mengevaluasi media foto untuk guru SD
Kecamatan Sukamakmur Kabupaten Bogor
Jawa Barat diharapkan nantinya pihak guru
yang terlibat dalam pelatihan ini mampu
untuk menerapkan ilmu yang sudah
diberikan pada kesehariannya saat proses
pembelajaran. Diharapkan nantinya, pihak
guru yang terlibat mampu untuk membuat
media foto yang disesuaikan dengan kondisi
yang ada. Media foto ini mampu untuk
menjangkau peserta didik yang banyak.
Sehingga peserta didik nantinya dapat
memahami materi yang akan disampaikan
oleh guru pada saat proses pembelajaran
berlangsung. Kegiatan yang dilakuna
berjalan lancar dan sangat baik.

\section{KESIMPULAN}

Penggunaan media visual foto hasil pendampingan pengabdian masyarakat ini dapat membantu peserta didik untuk menghubungkan materi pelajaran dengan lingkungan sekitar sehingga konsep dan materi yang sulit dipahami dapat dipelajari dengan mudah. Foto hasil pendampingan pengabdian masyarakat ini dapat digunakan sebagai media penyampaian pesan pembelajaran. Dalam penggunaannya dapat dibalik jika pesan dalam lembaran depan sudah ditampilkan dan diganti dengan lembaran berikutnya yang sudah disediakan. Foto yang dikembangkan sudah memenuhi kriteria layak secara teoritik dari ahli materi; memenuhi kriteria layak dari segi format, isi dan tampilan dari ahli media; memiliki keterterapan tinggi atau layak dalam pembelajaran menurut pengguna (guru dan siswa).

\section{UCAPAN TERIMA KASIH}

Ucapan terimakasih disampaikan kepada 1) Fakultas Ilmu Pendidikan Universitas Negeri Jakarta 2) Kepada Pemerintah Kecamatan Sukamakmur Kabupaten Bogor Jawa Barat, 3) Kepala Sekolah dan guru-guru di lingkungan Kecamatan Sukamakmur Kabupaten Bogor Jawa Barat, 4) Mahasiswa Program Studi Teknologi Pendidikan Fakultas Ilmu Pendidikan Universitas Negeri Jakarta

\section{DAFTAR PUSTAKA}

Asyad, Azhar. (2014). Media Pembelajaran. Jakarta: Rajawali Pers.

Gafur, Abdul. (2012). Desain Pembelajaran: Konsep, Model dan Aplikasinya dalam Perencanaan Pelaksanaan Pembelajaran. Yogyakarta: Ombak.

Indriana, Dina. 2011. Ragam Alat Bantu Media Pengajaran. Yogyakarta: Diva Press.

Jarumon Nookhong dan Panita Wannapiroon. (2015). Development of Collaborative Learning Using Case Based Learning Via Cloud Technology and Social Media for Enhancing Problem - Solving Skills and ICT Literacy Within Undergraduate Students. Procedia Social and Behavioral Sciences 174. 2096 - 2101.

Mudlofir, Ali dan Evi Fatimatur Rusydiyah. (2016). Desain Pembelajaran Inovatif: Dari Teori ke Praktik. Jakarta: RajaGrafindo Persada. 
Munir. (2010). Kurikulum Berbasis Teknologi Informasi dan Komunikasi.Bandung: Alfabeta.

Prasetya, Sukma Perdana. (2014). Media Pembelajaran Geografi. Yogyakarta: Ombak.

Prasetyo, Andhika Yoga, Triyono dan Imam Suyanto. (2012). Penggunaan Media Foto dalam Peningkatan Pembelajaran IPA di Sekolah Dasar. Jurnal PGSD FKIP UNS

Pratiwi, Desi Eka. (2013). Penerapan Media (Foto) Pada Pembelajaran Tematik Untuk Meningkatkan Hasil Belajar Siswa Sekolah Dasar.Jurnal Pendidikan Guru Sekolah Dasar, Vol. 01 No. 2, 0 - 216.

Riduwan. (2015). Skala Pengukuran Variabel $\quad-\quad$ variabel Penelitian.Bandung: Alfabeta.

Roesminingsih dan Lamijan Hadi Susarno. (2016). Teori dan Praktek Pendidikan. Surabaya: Fakultas Ilmu Pendidikan Universitas Negeri Surabaya.

Sadiman, dkk. (2014). Media Pendidikan, Pengertian, Pengembangan dan Pemanfaatannya. Jakarta: PT RajaGrafindo Persada.

Sagala, Syaiful. (2010). Konsep dan Makna Pembelajaran. Bandung: Alfabeta.

Sahlan, Asmaun dan Angga Teguh Prastyo. (2012). Desain Pembelajaran Berbasis Pendidikan Karakter. Yogyakarta: ArRuzz Media.

Sardiman. (2011). Interaksi dan Motivasi Belajar Mengajar. Jakarta: RajaGrafindo Persada.

Setiawan, Putu Zulvi dan Efendi Napitupulu. (2014). Aplikasi Media Pembelajaran Foto Untuk Meningkatkan Penguasaan Materi Pertumbuhan dan Perkembangan Pada Mata Pelajaran IPA Terpadu. Jurnal Teknologi Pendidikan, Vol. 7 No. 2 p-ISSN 1979 - 6692; e-ISSN 2407 - 7437.

StationaryCo. (2017). Papan White Board.Com. (Online), (http://www.stationary.co.id, diakses 07 Maret 2019).

Sugiyono. (2011). Metode Penelitian Kuantitatif Kualitatif dan R\&D. Bandung: Alfabeta.

Sundayana, Rostina. (2014). Media dan Alat Peraga dalam Pembelajaran Matematika. Bandung: Alfabeta.

Suprijono, Agus. (2014). Cooperative Learning: Teori dan Aplikasi PAIKEM. Yogyakarta: Pustaka Pelajar.

Susilana, Rudi dan Riyana. (2009). Media Pembelajaran: Hakikat, Pengembangan, Pemanfaatan dan Penilaian. Bandung: Wacana Prima.

Suyono dan Hariyanto. (2015). Belajar dan Pembelajaran: Teori dan Konsep Dasar. Bandung: PT Remaja Rosdakarya.

Teles, Sylker dan Kiyoshi Tomimatsu. (2014). Contextual Teaching and Learning Using a Card Game Interface. International Journal of Asia Digital Art \& Design.

Trianto. (2014). Mendesain Model Pembelajaran Inovatif - Progresif. Jakarta: Media Grup 